\title{
Memory T Cells in Flavivirus Vaccination
}

\author{
Guangyu Li ${ }^{1} \mathbb{D}$, Cody Teleki ${ }^{1}\left(\mathbb{D}\right.$ and Tian Wang ${ }^{1,2,3,4, *}$ \\ 1 Department of Microbiology \& Immunology, University of Texas Medical Branch, Galveston, TX 77555, USA; \\ guli@UTMB.EDU (G.L.); ccteleki@UTMB.EDU (C.T.) \\ 2 Department of Pathology, University of Texas Medical Branch, Galveston, TX 77555, USA \\ 3 Institute for Human Infections \& Immunity, University of Texas Medical Branch, Galveston, TX 77555, USA \\ 4 Sealy Institute for Vaccine Sciences, University of Texas Medical Branch, Galveston, TX 77555, USA \\ * Correspondence: ti1wang@utmb.edu
}

Received: 16 August 2018; Accepted: 12 October 2018; Published: 18 October 2018

check for updates

\begin{abstract}
Flaviviruses include many medically important viruses, such as Dengue virus (DENV), Japanese encephalitis (JEV), tick-borne encephalitis (TBEV), West Nile (WNV), yellow fever (YFV), and Zika viruses (ZIKV). Currently, there are licensed human vaccines for DENV, JEV, TBEV and YFV, but not for WNV or ZIKV. Memory T cells play a central role in adaptive immunity and are important for host protection during flavivirus infection. In this review, we discuss recent findings from animal models and clinical trials and provide new insights into the role of memory $\mathrm{T}$ cells in host protective immunity upon vaccination with the licensed flavivirus vaccines.
\end{abstract}

Keywords: flavivirus; memory T cells; vaccine

\section{Introduction}

Flaviviruses are a group of small, enveloped, positive-stranded RNA viruses. The $11 \mathrm{~kb}$ genome encodes, translates, and is processed into three structural proteins - capsid (C), envelope (E), membrane (M) - and seven non-structural (NS) proteins; NS1, NS2A, NS2B, NS3, NS4A, NS4B, and NS5. The E protein, a major virion surface protein, is involved in receptor binding and membrane fusion, and induces neutralizing antibodies in the infected hosts. Flavivirus genus includes more than 70 RNA viruses, many of which are mosquito or tick-borne human pathogens, such as dengue virus (DENV), Japanese encephalitis virus (JEV), tick-borne encephalitis virus (TBEV), West Nile virus (WNV), yellow fever virus (YFV), and Zika virus (ZIKV) [1,2]. Flavivirus infection can cause a wide variety of clinical manifestations and complications in humans ranging from undifferentiated fever, hemorrhagic fever, encephalitis and death. To date, there are no specific anti-viral therapeutics [3,4]. Vaccination has been one major preventive measure against flavivirus infection.

During viral infection, innate immunity provides immediate control of virus replication and dissemination. In comparison, adaptive immunity ( $\mathrm{T}$ cells and antibody-producing $\mathrm{B}$ cells) takes longer to develop, targets more specifically to viral antigens and plays a critical role in viral clearance and host recovery. Vaccination educates both innate and adaptive immune systems in order to boost adaptive $\mathrm{T}$ and $\mathrm{B}$ cell memory responses and provide rapid protection against subsequent infection with related viruses. Over the last seven decades, various strategies have been utilized to develop flavivirus vaccines. Currently, effective vaccines have been licensed for human use to combat YFV, JEV, DENV and TBEV infection. While it has been documented that neutralizing antibodies generated by these vaccines provide host protection, the role of $\mathrm{T}$ cell-mediated immunity is not yet fully understood. In this review, we focus on recent advances in understanding memory $\mathrm{T}$ cell responses to the licensed flavivirus (DENV, JEV, TBEV and YFV) vaccines, and the evidence of how they provide immune protection in humans or animal models. 


\section{Memory T Cell Responses to Flavivirus Infection}

\subsection{Memory T Cells}

During viral infection, naïve $\mathrm{T}$ cells become activated when they encounter cognate antigen presented by antigen-presenting cells (APCs) and differentiate into effector T cells. After a peak of the effector responses, the majority of activated $\mathrm{T}$ cells die during contraction phase and the remaining 5-10\% survive to acquire memory functions. Memory T cells recognize epitopes on conserved internal viral proteins, and respond more effectively following a secondary viral infection. They are central to all adaptive immune responses [5]. Memory $\mathrm{T}$ cells include central memory $\mathrm{T}$ cells $\left(\mathrm{T}_{\mathrm{CM}}\right)$, effector memory $T$ cells $\left(T_{E M}\right)$, tissue resident memory $T$ cells $\left(T_{R M}\right)$, and virtual memory $T$ cells $\left(T_{V M}\right)$ [6-11]. $\mathrm{CD}^{+}$and $\mathrm{CD}^{+}$memory $\mathrm{T}$ cells express CD45RO [12]. $\mathrm{T}_{\mathrm{CM}}$ stay in lymphoid organs and bone marrow and have a high proliferative potential. $\mathrm{T}_{\mathrm{EM}}$ are located in peripheral tissues, which enable them with immediate action on pathogen recognition. $\mathrm{T}_{\mathrm{RM}}$ settle within specific organs including intestines, lung, liver, spleen, brain, lymph node, skin and other mucosal surfaces, which play an important role on the protection against tissue-specific infections and mucosal infections [13,14]. $\mathrm{T}_{\mathrm{VM}}$ are antigen-inexperienced, but antigen-specific $\mathrm{T}$ cells, which can reside outside of the naïve $\mathrm{T}$ cell compartment and relate to physiological homeostatic mechanisms. Through homeostatic proliferation, memory T cells may persist life-long, even without antigen exposure $[6,7,15]$.

\subsection{T Cell Immunity in Flavivirus Infection}

Viral antigens are displayed on the surfaces of infected cells in the context of the major histocompatibility complex (MHC) Class I molecules, and are recognized by cytotoxic CD8 ${ }^{+} \mathrm{T}$ cells, which mediate the direct killing of virus-infected cells and produce anti-viral cytokines [16]. Meanwhile, $\mathrm{CD}^{+} \mathrm{T}$ cells recognize viral peptides associated with MHC class II, which is expressed by APCs. CD4 ${ }^{+}$ T cells carry out multiple functions, including activation of B-lymphocytes, cytotoxic T cells, as well as nonimmune cells, and also play a critical role in the suppression of immune reaction. Neutralizing antibodies have been primarily associated with epitopes on the E protein. Most T cell epitopes have been mapped in flavivirus NS proteins $[17,18]$. B cells and specific antibodies are critical in the control of disseminated flavivirus infection $[19,20]$. Both $\mathrm{CD}^{+}$and $\mathrm{CD}^{+}$effector and memory $\mathrm{T}$ cells have been shown to directly contribute to host protective immune responses, including viral clearance, and providing help for B cells and antibody maturation [21-27]. For example, CD4 ${ }^{+}$effector memory T cells expressing CD45RA (TEMRA) are implicated in protective immunity against DENV infection. An enhanced magnitude and functionality of $\mathrm{CD}^{+}{ }^{+}$TEMRA cells correlate with the human leukocyte antigen (HLA) allelic variants were associated with relative resistance to severe DENV diseases [28]. $\mathrm{CD}^{+}$cytotoxic $\mathrm{T}$ lymphocytes are known to protect host from DENV infection [29]. In another study [30], single-cell differential gene expression analysis revealed high levels of CD4 ${ }^{+}$cytotoxic T lymphocytes and precursor cells were enriched in the $\mathrm{T}_{\mathrm{EMRA}}$ subset. Lastly, the development of the polyfunctional tissue resident $\mathrm{CD}^{+}$memory $\mathrm{T}$ cells in the central nervous system (CNS) helps to control virus dissemination and decrease WNV lethality [31,32].

\section{Role of T Cells in Host Immunity against Flavivirus Vaccines}

\subsection{DENV}

\subsubsection{DENV Infection}

DENV has become one of the most important global public health threats in recent decades with nearly half the world's population living at the risk. There are four genetically and antigenically distinct DENV serotypes, including DENV1, DENV2, DENV3 and DENV4. DENV-induced clinical diseases range from asymptomatic infection, dengue fever to a life-threatening hemorrhagic disease (dengue hemorrhagic fever (DHF) and dengue shock syndrome (DSS)) [33]. 


\subsubsection{DENV Vaccine Development}

Currently, the only vaccine approved for human use is Dengvaxia (Table 1, CYD-TDV) developed by Sanofi Pasteur. CYD-TDV has been licensed in several countries, including Mexico, Brazil, El Salvador, Paraguay, and the Philippines. It is a recombinant live attenuated chimeric trivalent vaccine combination of four monovalent chimeric attenuated viruses that comprise the pre-membrane (prM) and E sequence of each DENV serotype grafted onto the NS protein backbone of YFV 17D [34]. The vaccine is known to elicit high neutralizing titers in vaccinees, but the overall protective efficacy across all four DENV serotypes was only 60.3\% [35]. While CYD-TDV is considered a first-generation vaccine, more efforts have been made towards the development of novel second-generation vaccines with improvements on both the protective efficacy and feasible dosing regimen usable for travelers or endemic market. Among them, several are in the advanced stages of clinical development [35]. One candidate, a live-attenuated tetravalent dengue vaccine (Takeda, TDV) consists of an attenuated DENV-2 strain (TDV-2), and three chimeric viruses containing the prM and E genes of DENV1, DENV3, and DENV4 expressed in the context of the TDV-2 genome (TDV-1, TDV-3, TDV-4, respectively). TDV (under the previous name DENVax) has been developed by Takeda Vaccines Inc. It has been extensively tested in preclinical studies and clinical trials. Another second-generation vaccine candidate is the live attenuated TV003/TV005 vaccine developed by US National Institutes of Health (NIH), which is in phase III development. It has been licensed to Merck, and companies in Brazil (Instituto Butantan), India (Panacea Biotec and Serum Institute of India), and Vietnam (Vabiotech). The attenuation of the vaccine was done by producing recombinant DEN viruses that carry nucleotide deletion in the $3^{\prime}$ untranslated region (UTR) or that were chimerized between DENV [36].

Table 1. Licensed human flavivirus vaccines.

\begin{tabular}{|c|c|c|c|}
\hline Virus & Vaccine Name & Vaccine Type & Developer \\
\hline \multirow{3}{*}{ DENV } & CYD-TDV (Dengvaxia) & Live attenuated & Sanofi Pasteur \\
\hline & TDV (DENVax) * & Live attenuated & Takeda Vaccines Inc. \\
\hline & TV003/005* & Live attenuated & $\mathrm{NIH}$ \\
\hline \multirow{4}{*}{ JEV } & SA14-14-2 & Live attenuated & BBIL, CDIBP \\
\hline & JE-CV; ChimeriVax-JE & Chimeric & Acambis/Saofi Pasteur \\
\hline & BK-VJE; JE-MB; JE-VC & Inactivated & BIKEN \\
\hline & IXIARO & Inactivated & Valneva Austria $\mathrm{GmbH}$ \\
\hline \multirow{5}{*}{ TBEV } & FSME-Immun & Inactivated & Baxter \\
\hline & Encepur & Inactivated & Novartis Vaccines \\
\hline & TBE-Moscow & Inactivated & $\begin{array}{c}\text { Federal State Enterprise of Chumakov Institute of } \\
\text { Poliomyelitis and Viral Encephalitides; Russian } \\
\text { Academy of Medical Sciences }\end{array}$ \\
\hline & Encevir & Inactivated & Scientific Production Association Microgen \\
\hline & TBE-PHK & Inactivated & Sen TaiBao, China \\
\hline \multirow{3}{*}{ YFV } & 17DD & Live attenuated & Bio-Manguinhos (Fiocruz) \\
\hline & 17D-204 & Live attenuated & $\begin{array}{c}\text { Sanofi Pasteur; Institute Pasteur; Wuhan Institute } \\
\text { of Biological Products, China }\end{array}$ \\
\hline & 17D-213 & Live attenuated & $\begin{array}{c}\text { Federal State Unitary Enterprise of Chumakov } \\
\text { Institute, Russia }\end{array}$ \\
\hline
\end{tabular}

\subsubsection{Memory T Cell Responses to DENV Vaccines}

An early phase II trial in Singapore [37] revealed that the CYD-TDV vaccine induced YF-17D-NS3-specific CD8 ${ }^{+} \mathrm{IFN} \gamma^{+} \mathrm{T}$ cell responses, and CYD-specific T helper $1 / \mathrm{T}$ cytotoxic 1 cellular response in all participants with a predominant IFN- $\gamma$ secretion compared with TNF- $\alpha$ and low levels of IL-13 following ex vivo re-stimulation of peripheral blood mononuclear cells (PBMC) with each the CYD vaccine viruses. Although DENV NS3-specific CD4 ${ }^{+} \mathrm{T}$ cell response pre-existed in adult 
participants, vaccination induced similar levels of CD4 $4^{+} \mathrm{TNF}-\alpha$ and IFN- $\gamma$ responses. Although T cell responses were directed mainly against CYD-4 after the first vaccination, they were more balanced against all four serotypes after the third immunization and the memory $\mathrm{T}$ cell response persisted after one year following CYD-TDV vaccination with 2- to 3-fold lower NS3-specific, and serotype-specific $\mathrm{T}$ cell activities [37]. The persistence of E-specific IFN- $\gamma$ secreting memory T cells was also reported in vaccinees 9 years after exposure to the live-attenuated vaccine [38].

In one clinical trial, Chu et al. [39] showed immunization with two doses of TDV vaccine 3 months apart triggered $\mathrm{CD}^{+} \mathrm{T}$ cells specific for the NS1, NS3, and NS5 proteins of TDV-2. In particular, CD8 ${ }^{+}$ T cells were multifunctional and cross-reactive to NS proteins of the other three DENV serotypes. CD8 ${ }^{+}$ $\mathrm{T}$ cell responses reached the peak levels on day 90 after the first dose and persisted 6 months following the second immunization. Animal studies also showed cross protection of the multifunctional CD8 ${ }^{+}$ $\mathrm{T}$ cell response after vaccination with live attenuated DENV2 PDK53, the core component of the tetravalent TDV vaccine, though the vaccinated mice developed enhancing, interfering maternal antibodies at the same time [40].

A randomized double-blind, placebo-controlled clinical trial was conducted in recipients of TV003 or placebo followed by challenge 6 months later with a DENV-2 strain, rDEN2 $\triangle 30$. All 21 recipients of TV003 who were challenged with $\mathrm{rDEN} 2 \Delta 30$ were protected from infection with $\mathrm{rDEN} 2 \Delta 30$. None developed viremia or any illness after challenge. In contrast, all 20 placebo recipients challenged with rDEN2 $\triangle 30$ developed viremia, and some developed rash or neutropenia [41]. Vaccination with TV003 not only elicits protective neutralizing antibodies, but also the antigen-specific CD8 ${ }^{+} \mathrm{T}$ cell response which were readily detectable and comparable to natural DENV infection. T cell responses following tetravalent vaccination were, dramatically, focused toward the highly conserved NS protein. Broad responses to structural and NS proteins were observed after monovalent vaccination [42]. Furthermore, $\mathrm{CD}^{+} \mathrm{T}$ cells elicited by a tetravalent live attenuated DENV vaccine (TV005) recognize epitopes identified in natural infection, and dominantly recognize the capsid, NS2A, and NS5 proteins. The vaccine-specific $\mathrm{CD} 4^{+} \mathrm{T}$ cell responses are similar in magnitude, frequency, and specificity to those observed in humans naturally exposed to DENV, suggesting that it would induce a $\mathrm{T}$ cell response protective against severe disease [43]. A more recent study [44] shows that the vaccine rDEN2 $\triangle 30$ induced stronger $\mathrm{CD} 8^{+} \mathrm{T}$ responses, but less $\mathrm{CD}^{+} \mathrm{T}$ cell responses than those to natural DENV2 infection, suggesting the differences between $\mathrm{CD} 4^{+}$and $\mathrm{CD} 8^{+} \mathrm{T}$ cell responses induced by vaccines compared to natural viruses infection. Furthermore, Paquin-Proulx, et al. [45] demonstrated that vaccination with the live, attenuated tetravalent vaccine TV003 induces a CD4 ${ }^{+} \mathrm{T}$-cell response against ZIKV, providing evidence for T cell cross-reactivity between DENV and ZIKV. Memory T cell responses elicited by prior vaccination with TV005 also recognize ZIKV-specific peptides. This cross-reactivity can be explained by the sequence similarity of the two viruses. DENV exposure prior to ZIKV infection also influences the timing and magnitude of the $\mathrm{T}$ cell response. ZIKV-reactive $\mathrm{T}$ cells in the acute phase of infection were detected earlier and in greater magnitude in DENV-immune patients [46].

\subsection{JEV}

\subsubsection{JEV Infection and Immunity}

The majority of JEV infections are asymptomatic; less than $1 \%$ of infections induce encephalitis. JE is the major viral encephalitis in South Asia and the Western Pacific [47]. Compared to other flaviviruses, JEV is more likely to induce severe neurological disease upon acute infection. The virus can also persist in the CNS and peripheral blood for several months after its initial acute infection [48,49]. Functional $\mathrm{CD}^{+}$and $\mathrm{CD}^{+} \mathrm{T}$ cell responses have been linked to different clinical outcomes of JEV infection. For example, JEV NS protein specific-CD8 ${ }^{+} \mathrm{T}$ cell responses were mostly observed in healthy JEV-exposed donors; whereas $\mathrm{CD} 4^{+} \mathrm{T}$ cell responses were noted in recovered JE patients, which targeted structural proteins and the secreted NS1 protein. Importantly, a high quality, poly-functional $\mathrm{CD} 4^{+} \mathrm{T}$ cell response was associated with a complete recovery from JE [50]. 


\subsubsection{Licensed JEV Vaccines}

Several different vaccines have been developed to control JE since the 1950s. Currently, inactivated, live attenuated and chimeric vaccines are licensed for human use, and are efficacious against more than one strain and genotype (Table 1, [47]). For more than half a century, the mouse brain derived inactivated (MBDI) vaccine was the only vaccine available for human use. However, the production of MBDI vaccine was discontinued in 2005 due to its poor immunogenicity and adverse events [47]. The Vero cell-derived inactivated vaccine has replaced the MBDI. The live attenuated SA14-14-2 JEV vaccine is the mostly commonly used JEV vaccine. It was derived from attenuating passages of a wild-type virus [51].The vaccine is completely attenuated for mice, tolerable for human use in both adults and children and it does not replicate in mosquitoes [47]. Vaccines usage has resulted in a decrease in JE incidence in many Asian countries. Nevertheless, JE remains a major problem in Asia. In addition, a low seroconversion of neutralization antibody was reported for the JEV vaccine SA 14-14-2 [51].

\subsubsection{T Cell Responses to Licensed JEV Vaccines}

The longevity of protective antibody responses induced by SA14-14-2 live-attenuated vaccine as well as the chimeric JEV vaccine have been well demonstrated [52,53]. The elicitation of $\mathrm{T}$ cell mediated immune responses and their long-term duration are not well understood yet. It has been shown that sublingual immunization with the live attenuated SA14-14-2 in mice induces JEV-specific IFN- $\gamma^{+} \mathrm{CD}^{+}$and $\mathrm{CD}^{+} \mathrm{T}$ cell responses [54]. In one clinical study in South India [55], $\mathrm{T}$ cell responses were evaluated following vaccination of 15 adults with a single dose of JEV live-attenuated vaccine SA14-14-2. Eighty-seven percent of participants produced IFN- $\gamma^{+} \mathrm{T}$ cell responses against JEV proteins. The inactivated vaccine was found to be less effective in protecting mice against JEV infection compared to the live attenuated vaccine [56]. High levels of IFN- $\gamma^{+} \mathrm{CD} 4^{+} \mathrm{T}$ cells were noted in female BALB/c mice vaccinated with JEV vaccine SA-14-14-2. In contrast, the inactivated vaccine only induced a limited immune response and partial protection, which may be due to the decreased activity of dendritic cells and the expansion of $\mathrm{CD} 4^{+} \mathrm{CD} 25^{+} \mathrm{Foxp}^{+}$regulatory $\mathrm{T}$ cells observed in vaccinated mice.

\subsection{TBEV}

\subsubsection{TBEV Infection and Vaccine Development}

TBEV causes mild to moderate febrile illness in humans that may progress to encephalitis, leading to severe long-term complications and sometimes death [57]. Currently, licensed TBEV vaccines include the Western European vaccines FSME-Immun and Ecepur, the Russian TBE-Moscow vaccine, EnceVir and the Chinese vaccine (Changchun Institute of Biological Products, China) (Table 1, [58]). In 2004, a second-generation inactivated vaccine produced in a primary hamster kidney (PHK) cell line (SenTaiBao, Changchun Institute of Biological Products Co., Ltd., Jilin, China) was approved in China for the prevention of TBE [59]. The Western European and Russian vaccines contain formalin-inactivated TBEV and aluminum hydroxide as an adjuvant and are both used in adults and children $[58,60]$. There is limited data published on the direct efficacy data for the second-generation, PHK-inactivated vaccine.

\subsubsection{T Cell Immunity and Host Protection in TBEV Vaccinees}

The mechanism of vaccine-induced protection against TBEV remains unclear. The formalin-inactivated tissue culture-derived virus vaccine is highly immunogenic and has been reported to induce protective neutralizing antibody responses after three doses [34]. Although neutralization antibodies stay persistently high 10 years following first booster vaccination [61], some animal studies showed that passive protection by neutralizing antibodies provide limited virus replication and protection from disease rather than sterilizing immunity [62]. While Eomes, Ki67 and T-bet identifies catalytic virus-specific $\mathrm{CD}^{+} \mathrm{T}$ cells in the peak effector stage of acute TBEV 
infection in patients; virus-specific $\mathrm{CD} 8^{+} \mathrm{T}$ cells transitioned to an Eomes $^{-} \mathrm{Ki}^{-} 7^{-}{ }^{-}$-bet ${ }^{+}$population as the infection resolved and memory was established [63]. One week after intramuscular vaccination with the FSME-IMMUN, $\mathrm{CD} 4^{+}$and $\mathrm{CD} 8^{+}$central and effector memory $\mathrm{T}$ cells increased. However, the overall changes in the $\mathrm{CD} 4^{+}$and $\mathrm{CD} 8^{+} \mathrm{T}$-cell subpopulations were small and did not show to have an impact on the distribution of the naïve and memory B-cell populations [64]. Further characterization of TBEV-specific $\mathrm{CD} 4^{+} \mathrm{T}$ cell response after an inactivated formalin-inactivated TBEV vaccine (FSME-Immun ${ }^{\circledR} 0.5 \mathrm{~mL}$, Baxter, Deerfield, IL, USA) in comparison to the response raised by natural infection were performed. Patients with TBEV infection had robust Th1 responses, producing IL-2, TNF- $\alpha$ and IFN- $\gamma$, which indicates that the responses are crucial for combating acute virus infection. In comparison, lower IFN $-\gamma$ responses and high proportions of TNF- $\alpha^{+}$IL-2 ${ }^{+} \mathrm{T}$ cells were noted following immunization with a formalin-inactivated TBEV vaccine [65]. Another study showed the magnitude of the TBEV-specific $\mathrm{CD}^{+} \mathrm{T}$ cell responses to capsid protein and $\mathrm{E}$ protein were significantly lower in patients with natural infection than in individuals immunized with an aluminum hydroxide-adjuvanted formalin-inactivated TBEV vaccine. This may be due to viral antagonism of the host immune response during infection or an enhanced $\mathrm{T}$ cell response after booster vaccination [66]. Overall, these studies suggest TBEV infection and vaccination induce differential $\mathrm{T}$ cell responses.

\subsection{YFV}

\subsubsection{YFV Infection and Vaccine Development}

YFV is endemic to tropical and subtropical regions of South America and Africa. Although a majority of human YFV infections are asymptomatic, severe YF occurs in about $12 \%$ of infected individuals and may manifest with jaundice, hemorrhage, and multisystem organ failure [67]. The YFV 17D live-attenuated vaccine was developed by Max Theiler and colleagues in 1930s, for which he won the Nobel Prize in 1951. Three 17D sub-strains (17D-204, 17DD, and 17D-213) are used as vaccines (Table 1), which have minor differences in genome sequences, but all have proved to be effective vaccines [68].

\subsubsection{Immune Mechanisms of Host Protection by YFV 17D Vaccination}

While it has been understood for many years now that YFV-17D vaccine elicits a strong humoral immune response, with neutralizing antibodies detectable in serum for over 30 years after vaccination, memory $\mathrm{CD}^{+} \mathrm{T}$ cells specific for the YFV-tetrameric antigen can also expand into effector pools at least 10 years after vaccination [69,70]. The mechanisms underlying YFV 17D efficacy have only been brought to light in the last several years. Recent evidence from animal models suggests that both humoral and cell-mediated immunity work in tandem to produce the lasting immunity seen following YFV 17D vaccination. Adoptive transfer of YFV-specific $\mathrm{CD}^{+} \mathrm{T}$ cells into naïve mice lacking the receptor to type I interferon before challenge with the Ang71 strain of YFV provided greater survival outcomes (5/8 survival rate) and less weight loss than mice that had received only $\mathrm{CD} 8^{+} \mathrm{T}$ cells ( $0 / 8$ survival rate). However, when given serum from immunized mice in combination with adoptive transfer of $\mathrm{CD}^{+}$and $\mathrm{CD} 8^{+} \mathrm{T}$ cells, the mice challenged with Ang71 had 100\% survival rates [71]. Bassi et al. [21] found that while YFV-specific memory $\mathrm{CD}^{+} \mathrm{T}$ cells were not required for protection against a challenge with YFV, they were trafficked into the brain with significantly higher kinetics than naive $\mathrm{CD} 8^{+} \mathrm{T}$ cells. When testing for differences in $\mathrm{CD} 4^{+}$trafficking to the brain, memory $\mathrm{CD} 4^{+} \mathrm{T}$ cells were not found significantly earlier in the brain than naïve $\mathrm{CD} 4^{+} \mathrm{T}$ cells. Ad-vector encoding the NS3 protein from YF-17D could elicit a strong $\mathrm{CD}^{+} \mathrm{T}$-cell response, which afforded a high degree of protection from subsequent intracranial challenge of the vaccinated mice [72]. Taken together, these studies point to a pivotal role of interactions between humoral and cell-mediated immunity in protecting against YFV infection. 


\subsubsection{Memory T Cell Development Following YFV 17D Vaccination}

In humans, $\mathrm{CD}^{+} \mathrm{T}$ cells seem to be biased towards a Th1-like response, as demonstrated by their rapid expression of CXCR3 following YFV 17D vaccination, and IFN- $\gamma$ expression when re-exposed to YFV antigen [73]. These YFV-specific Th1-like cells remain detectable at least five years after vaccination. Utilizing predictive algorithm software, Zhang et al. [74] identified three nonameric epitopes from YFV NS4A and NS4B proteins capable of eliciting a robust IFN- $\gamma^{+} \mathrm{CD}^{+} \mathrm{CD} 8^{+} \mathrm{T}$ cell response in YFV 17D-immunized mice. These epitopes were also found to be highly conserved across several strains of YFV, in addition to the YFV 17D vaccine strain. The effector functions of human CD8 ${ }^{+}$ T cells during the course of YFV 17D infection have been characterized. Blom et al. [75] found a decline in polyfunctional effector $\mathrm{CD}^{+} \mathrm{T}$ cells between days 10, 14, and 90 post-infection, corresponding to peak $\mathrm{CD}^{+}$, effector $\mathrm{CD}^{+}$, and effector memory $\mathrm{CD}^{+} \mathrm{T}$ cell response respectively. Additionally, monofunctional $\mathrm{CD}^{+} \mathrm{T}$ cells expressed CD107a during peak $\mathrm{CD} 4^{+} \mathrm{T}$ cell response, but later switched to produce TNF- $\alpha$ as their effector molecule. While YFV-specific memory CD8 ${ }^{+} \mathrm{T}$ cells express similar surface molecules as naïve CD8 ${ }^{+}$T cells, such as CD45RA, CCR7, CD127, and CD28 (all of which are distinct from effector $\mathrm{CD} 8^{+} \mathrm{T}$ cells), memory $\mathrm{T}$ cells have significantly faster proliferative kinetics than the naïve cells [76].

Akondy et al. [77] found that the degree of effector $C D 8^{+} \mathrm{T}$ cell expansion was related to the magnitude of viral load in 80 human volunteers. Those who experienced high viral load tended to have a larger effector $\mathrm{CD}^{+} \mathrm{T}$ cell response, and this was positively correlated with their memory $\mathrm{CD}^{+} \mathrm{T}$ cell response 90 days post-vaccination. Furthermore, in a murine model, Neves et al. [78] showed that higher initial IFN- $\gamma$ production by $\gamma \delta \mathrm{T}$ cells in lymph nodes following vaccination with YFV 17D correlated with increased cytokine response by IFN- $\gamma^{+} \mathrm{CD} 4^{+}$and IFN- $\gamma^{+} \mathrm{CD} 8^{+}$cells. They also hypothesized that the larger initial IFN- $\gamma$ response was due to increased viral replication within dendritic cells. Nevertheless, the clinical study conducted in African populations showed that an activated immune microenvironment including activation of $\mathrm{CD}^{+} \mathrm{T}$ cells and B cells as well as proinflammatory monocytes prior to vaccination are associated with impaired YFV-17D-induced CD8 ${ }^{+}$ $\mathrm{T}$ cell responses [79]. Furthermore, a recent study showed the magnitudes of secondary responses induced by YFV-17D were much reduced compared to primary responses. In particular, the frequency and functional responses of total activated YFV-specific CD4 ${ }^{+}$and $\mathrm{CD}^{+} \mathrm{T}$ cells were reduced [80]. These results may argue that immunizing naïve individuals at risk is a priority and a more efficient use of available vaccine supplies. Collectively, these findings suggest both immune status prior to vaccination and virus replication contribute to memory $\mathrm{T}$ cell development upon vaccination. Further characterization of $\mathrm{CD}^{+}$memory $\mathrm{T}$ cells also revealed that the memory pool divided extensively during the first two weeks after infection and is maintained by quiescent cells that divide less than once every year. Unlike effector $\mathrm{CD}^{+} \mathrm{T}$ cells, memory $\mathrm{CD}^{+} \mathrm{T}$ cells do not produce the cytotoxic effector proteins granzyme B or perforin. However, patterns of CpG methylation at the granzyme B and perforin promoters did not significantly differ between the two cell populations, suggesting an epigenetic role in maintaining a lasting memory $\mathrm{CD}^{+} \mathrm{T}$ cells [76].

\section{Conclusions}

Although neutralizing antibody titer is the FDA-accepted primary endpoint of vaccine immunogenicity for flavivirus vaccines, increasing evidence suggests that neutralizing antibody only mildly correlates with protection. T cell mediated immunity may play a protective role in the absence of neutralizing antibody [76,81,82]. Clinical trials and animal studies of the currently licensed human flavivirus vaccines further support that T cells, in particular, multifunctional CD4 ${ }^{+}$and $\mathrm{CD} 8^{+}$ memory $\mathrm{T}$ cell responses which have similar magnitude, frequency and specificity as those of natural infection contribute to a safe, efficacious and durable vaccine. In addition, immune status prior vaccination and epigenetic factors both contribute to the development and maintaining of memory $\mathrm{T}$ cells. These findings will likely provide new strategies for current development and licensure of WNV and ZIKV vaccines. 
Author Contributions: Original Draft Preparation: G.L. and C.T.; Funding Acquisition, Writing, Review and Editing: T.W.

Funding: This work was supported in part by NIH grant R01 AI099123 (T.W.), R01AI127744 (T.W.) and a grant from Sealy Institute for Vaccine Sciences at UTMB (T.W.). C.T. was a recipient of a summer internship from NIAID T35 training grant (AI078878, PI: L Soong).

Conflicts of Interest: The authors declare no conflicts of interest.

\section{References}

1. Lindenbach, B.D.; Murray, C.L.; Thiel, H.J.; Rice, C.M. Flaviviridae; Lippincott Williams \& Wilkins: Philadelphia, PA, USA, 2013.

2. Luo, H.; Winkelmann, E.R.; Fernandez-Salas, I.; Li, L.; Mayer, S.V.; Danis-Lozano, R.; Sanchez-Casas, R.M.; Vasilakis, N.; Tesh, R.; Barrett, A.D.; et al. Zika, dengue and yellow fever viruses induce differential anti-viral immune responses in human monocytic and first trimester trophoblast cells. Antivir. Res. 2018, 151, 55-62. [CrossRef] [PubMed]

3. Aktepe, T.E.; Mackenzie, J.M. Shaping the flavivirus replication complex: It is curvaceous! Cell. Microbiol. 2018, 20, e12884. [CrossRef] [PubMed]

4. Weaver, S.C.; Charlier, C.; Vasilakis, N.; Lecuit, M. Zika, Chikungunya, and other emerging vector-borne viral diseases. Annu. Rev. Med. 2017. [CrossRef] [PubMed]

5. Omilusik, K.D.; Goldrath, A.W. The origins of memory T cells. Nature 2017, 552, 337-339. [CrossRef] [PubMed]

6. Lee, Y.J.; Jameson, S.C.; Hogquist, K.A. Alternative memory in the CD8 T cell lineage. Trends Immunol. 2011, 32, 50-56. [CrossRef] [PubMed]

7. Marusina, A.I.; Ono, Y.; Merleev, A.A.; Shimoda, M.; Ogawa, H.; Wang, E.A.; Kondo, K.; Olney, L.; Luxardi, G.; Miyamura, Y.; et al. CD4(+) virtual memory: Antigen-inexperienced T cells reside in the naive, regulatory, and memory $\mathrm{T}$ cell compartments at similar frequencies, implications for autoimmunity. J. Autoimmun. 2017, 77, 76-88. [CrossRef] [PubMed]

8. Sallusto, F.; Lenig, D.; Forster, R.; Lipp, M.; Lanzavecchia, A. Two subsets of memory T lymphocytes with distinct homing potentials and effector functions. Nature 1999, 401, 708-712. [CrossRef] [PubMed]

9. Shin, H.; Iwasaki, A. Tissue-resident memory T cells. Immunol. Rev. 2013, 255, 165-181. [CrossRef] [PubMed]

10. White, J.T.; Cross, E.W.; Kedl, R.M. Antigen-inexperienced memory CD8(+) T cells: Where they come from and why we need them. Nat. Rev. Immunol. 2017, 17, 391-400. [CrossRef] [PubMed]

11. Willinger, T.; Freeman, T.; Hasegawa, H.; McMichael, A.J.; Callan, M.F. Molecular signatures distinguish human central memory from effector memory CD8 T cell subsets. J. Immunol. 2005, 175, 5895-5903. [CrossRef] [PubMed]

12. Akbar, A.N.; Terry, L.; Timms, A.; Beverley, P.C.; Janossy, G. Loss of CD45R and gain of UCHL1 reactivity is a feature of primed T cells. J. Immunol. 1988, 140, 2171-2178. [PubMed]

13. Kumar, B.V.; Ma, W.; Miron, M.; Granot, T.; Guyer, R.S.; Carpenter, D.J.; Senda, T.; Sun, X.; Ho, S.H.; Lerner, H.; et al. Human Tissue-Resident Memory T Cells Are Defined by Core Transcriptional and Functional Signatures in Lymphoid and Mucosal Sites. Cell Rep. 2017, 20, 2921-2934. [CrossRef] [PubMed]

14. Mueller, S.N.; Mackay, L.K. Tissue-resident memory T cells: Local specialists in immune defence. Nat. Rev. Immunol. 2016, 16, 79-89. [CrossRef] [PubMed]

15. White, J.T.; Cross, E.W.; Burchill, M.A.; Danhorn, T.; McCarter, M.D.; Rosen, H.R.; O'Connor, B.; Kedl, R.M. Virtual memory $\mathrm{T}$ cells develop and mediate bystander protective immunity in an IL-15-dependent manner. Nat. Commun. 2016, 7, 11291. [CrossRef] [PubMed]

16. Andersen, M.H.; Schrama, D.; Thor Straten, P.; Becker, J.C. Cytotoxic T cells. J. Investig. Dermatol. 2006, 126, 32-41. [CrossRef] [PubMed]

17. Pierson, T.C.; Fremont, D.H.; Kuhn, R.J.; Diamond, M.S. Structural insights into the mechanisms of antibody-mediated neutralization of flavivirus infection: Implications for vaccine development. Cell Host Microbe 2008, 4, 229-238. [CrossRef] [PubMed]

18. Weiskopf, D.; Sette, A. T-cell immunity to infection with dengue virus in humans. Front. Immunol. 2014, 5, 93. [CrossRef] [PubMed] 
19. Diamond, M.S.; Shrestha, B.; Marri, A.; Mahan, D.; Engle, M. B cells and antibody play critical roles in the immediate defense of disseminated infection by West Nile encephalitis virus. J. Virol. 2003, 77, 2578-2586. [CrossRef] [PubMed]

20. Roehrig, J.T.; Staudinger, L.A.; Hunt, A.R.; Mathews, J.H.; Blair, C.D. Antibody prophylaxis and therapy for flavivirus encephalitis infections. Ann. N. Y. Acad. Sci. 2001, 951, 286-297. [CrossRef] [PubMed]

21. Bassi, M.R.; Kongsgaard, M.; Steffensen, M.A.; Fenger, C.; Rasmussen, M.; Skjodt, K.; Finsen, B.; Stryhn, A.; Buus, S.; Christensen, J.P.; et al. CD8+ T cells complement antibodies in protecting against yellow fever virus. J. Immunol. 2015, 194, 1141-1153. [CrossRef] [PubMed]

22. Michlmayr, D.; Bardina, S.V.; Rodriguez, C.A.; Pletnev, A.G.; Lim, J.K. Dual function of Ccr5 during Langat virus encephalitis: Reduction in neutrophil-mediated central nervous system inflammation and increase in $\mathrm{T}$ cell-mediated viral clearance. J. Immunol. 2016, 196, 4622-4631. [CrossRef] [PubMed]

23. Elong Ngono, A.; Vizcarra, E.A.; Tang, W.W.; Sheets, N.; Joo, Y.; Kim, K.; Gorman, M.J.; Diamond, M.S.; Shresta, S. Mapping and role of the CD8(+) T cell response during primary Zika virus infection in mice. Cell Host Microbe 2017, 21, 35-46. [CrossRef] [PubMed]

24. Larena, M.; Regner, M.; Lee, E.; Lobigs, M. Pivotal role of antibody and subsidiary contribution of CD8+ $\mathrm{T}$ cells to recovery from infection in a murine model of Japanese encephalitis. J. Virol. 2011, 85, 5446-5455. [CrossRef] [PubMed]

25. Mathews, J.H.; Roehrig, J.T.; Brubaker, J.R.; Hunt, A.R.; Allan, J.E. A synthetic peptide to the E glycoprotein of Murray Valley encephalitis virus defines multiple virus-reactive T- and B-cell epitopes. J. Virol. 1992, 66, 6555-6562. [PubMed]

26. Sitati, E.M.; Diamond, M.S. CD4+ T-cell responses are required for clearance of West Nile virus from the central nervous system. J. Virol. 2006, 80, 12060-12069. [CrossRef] [PubMed]

27. Yauch, L.E.; Zellweger, R.M.; Kotturi, M.F.; Qutubuddin, A.; Sidney, J.; Peters, B.; Prestwood, T.R.; Sette, A.; Shresta, S. A protective role for dengue virus-specific CD8+ T cells. J. Immunol. 2009, 182, 4865-4873. [CrossRef] [PubMed]

28. Tian, Y.; Babor, M.; Lane, J.; Schulten, V.; Patil, V.S.; Seumois, G.; Rosales, S.L.; Fu, Z.; Picarda, G.; Burel, J.; et al. Unique phenotypes and clonal expansions of human CD4 effector memory $\mathrm{T}$ cells re-expressing CD45RA. Nat. Commun. 2017, 8, 1473. [CrossRef] [PubMed]

29. Weiskopf, D.; Bangs, D.J.; Sidney, J.; Kolla, R.V.; De Silva, A.D.; de Silva, A.M.; Crotty, S.; Peters, B.; Sette, A. Dengue virus infection elicits highly polarized CX3CR1+ cytotoxic CD4+ T cells associated with protective immunity. Proc. Natl. Acad. Sci. USA 2015, 112, E4256-E4263. [CrossRef] [PubMed]

30. Patil, V.S.; Madrigal, A.; Schmiedel, B.J.; Clarke, J.; O’Rourke, P.; de Silva, A.D.; Harris, E.; Peters, B.; Seumois, G.; Weiskopf, D.; et al. Precursors of human CD4(+) cytotoxic T lymphocytes identified by single-cell transcriptome analysis. Sci. Immunol. 2018, 3. [CrossRef] [PubMed]

31. Aguilar-Valenzuela, R.; Netland, J.; Seo, Y.J.; Bevan, M.J.; Grakoui, A.; Suthar, M.S. Dynamics of tissue-specific CD8(+) T cell responses during West Nile virus infection. J. Virol. 2018, 92. [CrossRef] [PubMed]

32. Graham, J.B.; Da Costa, A.; Lund, J.M. Regulatory T cells shape the resident memory T cell response to virus infection in the tissues. J. Immunol. 2014, 192, 683-690. [CrossRef] [PubMed]

33. Fernandez-Garcia, M.D.; Mazzon, M.; Jacobs, M.; Amara, A. Pathogenesis of flavivirus infections: Using and abusing the host cell. Cell Host Microbe 2009, 5, 318-328. [CrossRef] [PubMed]

34. Collins, M.H.; Metz, S.W. Progress and works in progress: Update on flavivirus vaccine development. Clin. Ther. 2017, 39, 1519-1536. [CrossRef] [PubMed]

35. Hadinegoro, S.R.; Arredondo-Garcia, J.L.; Capeding, M.R.; Deseda, C.; Chotpitayasunondh, T.; Dietze, R.; Muhammad Ismail, H.I.; Reynales, H.; Limkittikul, K.; Rivera-Medina, D.M.; et al. Efficacy and long-term safety of a dengue vaccine in regions of endemic disease. N. Engl. J. Med. 2015, 373, 1195-1206. [CrossRef] [PubMed]

36. Torresi, J.; Ebert, G.; Pellegrini, M. Vaccines licensed and in clinical trials for the prevention of dengue. Hum. Vaccines Immunother. 2017, 13, 1059-1072. [CrossRef] [PubMed]

37. Harenberg, A.; Begue, S.; Mamessier, A.; Gimenez-Fourage, S.; Seah, C.C.; Liang, A.W.; Ng, J.L.; Toh, X.Y.; Archuleta, S.; Wilder-Smith, A.; et al. Persistence of Th1/Tc1 responses one year after tetravalent dengue vaccination in adults and adolescents in Singapore. Hum. Vaccines Immunother. 2013, 9, 2317-2325. [CrossRef] 
38. Sun, P.; Simmons, M. Dendritic cell-based ELISpot assay for assessing T-cell IFN-gamma responses in human peripheral blood mononuclear cells to dengue envelope proteins. Methods Mol. Boil. 2018, 1808, 187-196. [CrossRef]

39. Chu, H.; George, S.L.; Stinchcomb, D.T.; Osorio, J.E.; Partidos, C.D. CD8+ T-cell responses in flavivirus-naive individuals following immunization with a live-attenuated tetravalent dengue vaccine candidate. J. Infect. Dis. 2015, 212, 1618-1628. [CrossRef] [PubMed]

40. Lam, J.H.; Chua, Y.L.; Lee, P.X.; Martinez Gomez, J.M.; Ooi, E.E.; Alonso, S. Dengue vaccine-induced CD8+ T cell immunity confers protection in the context of enhancing, interfering maternal antibodies. JCI Insight 2017, 2. [CrossRef] [PubMed]

41. Kirkpatrick, B.D.; Whitehead, S.S.; Pierce, K.K.; Tibery, C.M.; Grier, P.L.; Hynes, N.A.; Larsson, C.J.; Sabundayo, B.P.; Talaat, K.R.; Janiak, A.; et al. The live attenuated dengue vaccine TV003 elicits complete protection against dengue in a human challenge model. Sci. Transl. Med. 2016, 8, 330-336. [CrossRef] [PubMed]

42. Weiskopf, D.; Angelo, M.A.; Bangs, D.J.; Sidney, J.; Paul, S.; Peters, B.; de Silva, A.D.; Lindow, J.C.; Diehl, S.A.; Whitehead, S.; et al. The human CD8+ T cell responses induced by a live attenuated tetravalent dengue vaccine are directed against highly conserved epitopes. J. Virol. 2015, 89, 120-128. [CrossRef] [PubMed]

43. Angelo, M.A.; Grifoni, A.; O’Rourke, P.H.; Sidney, J.; Paul, S.; Peters, B.; de Silva, A.D.; Phillips, E.; Mallal, S.; Diehl, S.A.; et al. Human CD4(+) T cell responses to an attenuated tetravalent dengue vaccine parallel those induced by natural infection in magnitude, HLA restriction, and antigen specificity. J. Virol. 2017, 91. [CrossRef] [PubMed]

44. Grifoni, A.; Angelo, M.; Sidney, J.; Paul, S.; Peters, B.; de Silva, A.D.; Phillips, E.; Mallal, S.; Diehl, S.A.; Botten, J.; et al. Patterns of cellular immunity associated with experimental infection with rDEN2Delta30 (Tonga /74) support its suitability as a human dengue virus challenge strain. J. Virol. 2017, 91. [CrossRef]

45. Paquin-Proulx, D.; Leal, F.E.; Terrassani Silveira, C.G.; Maestri, A.; Brockmeyer, C.; Kitchen, S.M.; Cabido, V.D.; Kallas, E.G.; Nixon, D.F. T-cell responses in individuals infected with Zika virus and in those vaccinated against Dengue virus. Pathog. Immun. 2017, 2, 274-292. [CrossRef] [PubMed]

46. Grifoni, A.; Pham, J.; Sidney, J.; O’Rourke, P.H.; Paul, S.; Peters, B.; Martini, S.R.; de Silva, A.D.; Ricciardi, M.J.; Magnani, D.M.; et al. Prior Dengue virus exposure shapes T cell immunity to Zika virus in humans. J. Virol. 2017. [CrossRef] [PubMed]

47. Hegde, N.R.; Gore, M.M. Japanese encephalitis vaccines: Immunogenicity, protective efficacy, effectiveness, and impact on the burden of disease. Hum. Vaccines Immunother. 2017, 13, 1-18. [CrossRef] [PubMed]

48. Ravi, V.; Desai, A.S.; Shenoy, P.K.; Satishchandra, P.; Chandramuki, A.; Gourie-Devi, M. Persistence of Japanese encephalitis virus in the human nervous system. J. Med. Virol. 1993, 40, 326-329. [CrossRef] [PubMed]

49. Sharma, S.; Mathur, A.; Prakash, V.; Kulshreshtha, R.; Kumar, R.; Chaturvedi, U.C. Japanese encephalitis virus latency in peripheral blood lymphocytes and recurrence of infection in children. Clin. Exp. Immunol. 1991, 85, 85-89. [CrossRef] [PubMed]

50. Turtle, L.; Bali, T.; Buxton, G.; Chib, S.; Chan, S.; Soni, M.; Hussain, M.; Isenman, H.; Fadnis, P.; Venkataswamy, M.M.; et al. Human T cell responses to Japanese encephalitis virus in health and disease. J. Exp. Med. 2016, 213, 1331-1352. [CrossRef] [PubMed]

51. Turtle, L.; Solomon, T. Japanese encephalitis-the prospects for new treatments. Nat. Rev. Neurol. 2018, 14, 298-313. [CrossRef] [PubMed]

52. Feroldi, E.; Boaz, M.; Yoksan, S.; Chokephaibulkit, K.; Thisyakorn, U.; Pancharoen, C.; Monfredo, C.; Bouckenooghe, A. Persistence of wild-type Japanese Encephalitis virus strains cross-neutralization 5 years after JE-CV immunization. J. Infect. Dis. 2017, 215, 221-227. [CrossRef] [PubMed]

53. Sohn, Y.M.; Tandan, J.B.; Yoksan, S.; Ji, M.; Ohrr, H. A 5-year follow-up of antibody response in children vaccinated with single dose of live attenuated SA14-14-2 Japanese encephalitis vaccine: Immunogenicity and anamnestic responses. Vaccine 2008, 26, 1638-1643. [CrossRef] [PubMed]

54. Lee, E.Y.; Kim, J.Y.; Lee, D.K.; Yoon, I.S.; Ko, H.L.; Chung, J.W.; Chang, J.; Nam, J.H. Sublingual immunization with Japanese encephalitis virus vaccine effectively induces immunity through both cellular and humoral immune responses in mice. Microbiol. Immunol. 2016, 60, 846-853. [CrossRef] [PubMed]

55. Turtle, L.; Tatullo, F.; Bali, T.; Ravi, V.; Soni, M.; Chan, S.; Chib, S.; Venkataswamy, M.M.; Fadnis, P.; Yaich, M.; et al. Cellular immune responses to live attenuated Japanese Encephalitis (JE) vaccine SA14-14-2 in adults in a JE/Dengue co-endemic area. PLoS Negl. Trop. Dis. 2017, 11, e0005263. [CrossRef] [PubMed] 
56. Li, J.; Chen, H.; Wu, N.; Fan, D.; Liang, G.; Gao, N.; An, J. Characterization of immune responses induced by inactivated, live attenuated and DNA vaccines against Japanese encephalitis virus in mice. Vaccine 2013, 31, 4136-4142. [CrossRef] [PubMed]

57. Haglund, M.; Gunther, G. Tick-borne encephalitis-pathogenesis, clinical course and long-term follow-up. Vaccine 2003, 21 (Suppl. S1), S11-S18. [CrossRef]

58. Smit, R.; Postma, M.J. Review of tick-borne encephalitis and vaccines: Clinical and economical aspects. Expert Rev. Vaccines 2015, 14, 737-747. [CrossRef] [PubMed]

59. Yoshii, K.; Song, J.Y.; Park, S.B.; Yang, J.; Schmitt, H.J. Tick-borne encephalitis in Japan, Republic of Korea and China. Emerg. Microbes Infect. 2017, 6, e82. [CrossRef] [PubMed]

60. Kollaritsch, H.; Paulke-Korinek, M.; Holzmann, H.; Hombach, J.; Bjorvatn, B.; Barrett, A. Vaccines and vaccination against tick-borne encephalitis. Expert Rev. Vaccines 2012, 11, 1103-1119. [CrossRef] [PubMed]

61. Beran, J.; Lattanzi, M.; Xie, F.; Moraschini, L.; Galgani, I. Second five-year follow-up after a booster vaccination against tick-borne encephalitis following different primary vaccination schedules demonstrates at least 10years antibody persistence. Vaccine 2018. [CrossRef] [PubMed]

62. Kreil, T.R.; Maier, E.; Fraiss, S.; Attakpah, E.; Burger, I.; Mannhalter, J.W.; Eibl, M.M. Vaccination against tick-borne encephalitis virus, a flavivirus, prevents disease but not infection, although viremia is undetectable. Vaccine 1998, 16, 1083-1086. [CrossRef]

63. Blom, K.; Braun, M.; Pakalniene, J.; Dailidyte, L.; Beziat, V.; Lampen, M.H.; Klingstrom, J.; Lagerqvist, N.; Kjerstadius, T.; Michaelsson, J.; et al. Specificity and dynamics of effector and memory CD8 T cell responses in human tick-borne encephalitis virus infection. PLoS Pathog. 2015, 11, e1004622. [CrossRef] [PubMed]

64. Schwaiger, H.S.; Garner-Spitzer, E.; Hofer, M.; Kundi, M.; Wiedermann, U. Comparable immune responsiveness but increased reactogenicity after subcutaneous versus intramuscular administration of tick borne encephalitis (TBE) vaccine. Vaccine 2016, 34, 2027-2034. [CrossRef]

65. Aberle, J.H.; Schwaiger, J.; Aberle, S.W.; Stiasny, K.; Scheinost, O.; Kundi, M.; Chmelik, V.; Heinz, F.X. Human CD4+ T helper cell responses after tick-borne encephalitis vaccination and infection. PLoS ONE 2015, 10, e0140545. [CrossRef] [PubMed]

66. Schwaiger, J.; Aberle, J.H.; Stiasny, K.; Knapp, B.; Schreiner, W.; Fae, I.; Fischer, G.; Scheinost, O.; Chmelik, V.; Heinz, F.X. Specificities of human CD4+ T cell responses to an inactivated flavivirus vaccine and infection: Correlation with structure and epitope prediction. J. Virol. 2014, 88, 7828-7842. [CrossRef] [PubMed]

67. Waggoner, J.J.; Rojas, A.; Pinsky, B.A. Yellow fever virus: Diagnostics for a persistent arboviral threat. J. Clin. Microbiol. 2018. [CrossRef] [PubMed]

68. Barrett, A.D. Yellow fever in Angola and Beyond-The problem of vaccine supply and demand. N. Engl. J. Med. 2016, 375, 301-303. [CrossRef] [PubMed]

69. Poland, J.D.; Calisher, C.H.; Monath, T.P.; Downs, W.G.; Murphy, K. Persistence of neutralizing antibody 30-35 years after immunization with 17D yellow fever vaccine. Bull. World Health Organ. 1981, 59, 895-900. [PubMed]

70. Wieten, R.W.; Jonker, E.F.F.; Leeuwen, E.M.M.V.; Remmerswaal, E.B.M.; Berge, I.J.M.T.; Visser, A.W.D.; Genderen, P.J.J.V.; Goorhuis, A.; Visser, L.G.; Grobusch, M.P.; et al. A single 17D yellow fever vaccination provides lifelong immunity; characterization of yellow-fever-specific neutralizing antibody and T-cell responses after vaccination. PLoS ONE 2016, 11, e0149871. [CrossRef] [PubMed]

71. Watson, A.M.; Lam, L.K.; Klimstra, W.B.; Ryman, K.D. The 17D-204 vaccine strain-induced protection against virulent yellow fever virus is mediated by humoral immunity and CD4+ but not CD8+ T cells. PLoS Pathog. 2016, 12, e1005786. [CrossRef] [PubMed]

72. Bassi, M.R.; Larsen, M.A.; Kongsgaard, M.; Rasmussen, M.; Buus, S.; Stryhn, A.; Thomsen, A.R.; Christensen, J.P. Vaccination with replication deficient adenovectors encoding YF-17D antigens induces long-lasting protection from severe yellow fever virus infection in mice. PLoS Negl. Trop. Dis. 2016, 10, e0004464. [CrossRef] [PubMed]

73. James, E.A.; LaFond, R.E.; Gates, T.J.; Mai, D.T.; Malhotra, U.; Kwok, W.W. Yellow fever vaccination elicits broad functional CD4+ T cell responses that recognize structural and nonstructural proteins. J. Virol. 2013, 87, 12794-12804. [CrossRef] [PubMed]

74. Zhang, W.; Li, X.; Lin, Y.; Tian, D. Identification of three H-2Kd restricted CTL epitopes of NS4A and NS4B protein from Yellow fever 17D vaccine. J. Virol. Methods 2013, 187, 304-313. [CrossRef] [PubMed] 
75. Blom, K.; Braun, M.; Ivarsson, M.A.; Gonzalez, V.D.; Falconer, K.; Moll, M.; Ljunggren, H.G.; Michaelsson, J.; Sandberg, J.K. Temporal dynamics of the primary human $\mathrm{T}$ cell response to yellow fever virus 17D as it matures from an effector- to a memory-type response. J. Immunol. 2013, 190, 2150-2158. [CrossRef] [PubMed]

76. Akondy, R.S.; Fitch, M.; Edupuganti, S.; Yang, S.; Kissick, H.T.; Li, K.W.; Youngblood, B.A.; Abdelsamed, H.A.; McGuire, D.J.; Cohen, K.W.; et al. Origin and differentiation of human memory CD8 T cells after vaccination. Nature 2017, 552, 362-367. [CrossRef] [PubMed]

77. Akondy, R.S.; Johnson, P.L.; Nakaya, H.I.; Edupuganti, S.; Mulligan, M.J.; Lawson, B.; Miller, J.D.; Pulendran, B.; Antia, R.; Ahmed, R. Initial viral load determines the magnitude of the human CD8 T cell response to yellow fever vaccination. Proc. Natl. Acad. Sci. USA 2015, 112, 3050-3055. [CrossRef] [PubMed]

78. Neves, P.C.C.; Santos, J.R.; Tubarão, L.N.; Bonaldo, M.C.; Galler, R. Early IFN-gamma production after YF $17 \mathrm{D}$ vaccine virus immunization in mice and its association with adaptive immune responses. PLoS ONE 2013, 8, e81953. [CrossRef] [PubMed]

79. Muyanja, E.; Ssemaganda, A.; Ngauv, P.; Cubas, R.; Perrin, H.; Srinivasan, D.; Canderan, G.; Lawson, B.; Kopycinski, J.; Graham, A.S.; et al. Immune activation alters cellular and humoral responses to yellow fever 17D vaccine. J. Clin. Investig. 2014, 124, 3147-3158. [CrossRef] [PubMed]

80. Kongsgaard, M.; Bassi, M.R.; Rasmussen, M.; Skjodt, K.; Thybo, S.; Gabriel, M.; Hansen, M.B.; Christensen, J.P.; Thomsen, A.R.; Buus, S.; et al. Adaptive immune responses to booster vaccination against yellow fever virus are much reduced compared to those after primary vaccination. Sci. Rep. 2017, 7, 662. [CrossRef] [PubMed]

81. Halstead, S.B. Achieving safe, effective, and durable Zika virus vaccines: Lessons from dengue. Lancet Infect. Dis. 2017, 17, e378-e382. [CrossRef]

82. Sabchareon, A.; Wallace, D.; Sirivichayakul, C.; Limkittikul, K.; Chanthavanich, P.; Suvannadabba, S.; Jiwariyavej, V.; Dulyachai, W.; Pengsaa, K.; Wartel, T.A.; et al. Protective efficacy of the recombinant, live-attenuated, CYD tetravalent dengue vaccine in Thaischoolchildren: A randomised, controlled phase $2 \mathrm{~b}$ trial. Lancet 2012, 380, 1559-1567. [CrossRef]

(C) 2018 by the authors. Licensee MDPI, Basel, Switzerland. This article is an open access article distributed under the terms and conditions of the Creative Commons Attribution (CC BY) license (http:/ / creativecommons.org/licenses/by/4.0/). 